\title{
Risk Assessment of Urban Gas Pipeline Based on Different Unknown Measure Functions
}

\author{
Kai SHENG, Xiaolin LAI, Yong CHEN, Juncheng JIANG, Lin ZHOU*
}

\begin{abstract}
Several risk factors threaten the safety of urban gas pipeline. How to effectively identify various risk factors affecting urban gas pipeline and put forward scientific risk assessment method is the focus in the field of urban safety research. To explore the uncertain factors in the process of gas pipeline risk assessment, and propose a practical assessment method, a three-layer index system for the risk assessment of urban gas pipeline was established using unascertained measure theory, which included 5 first-class evaluation factors and 34 second-class evaluation indexes. Four unascertained measure models (linear, parabolic, exponential and sinusoidal) were constructed, and the unascertained measure values of each evaluation index under four unknown measure function models were calculated. The weight of evaluation factors was determined by Analytic Hierarchy Process (AHP), and the confidence criterion was used for discriminant evaluation. Results demonstrate that the risk assessment models constructed with different measurement functions can effectively reduce the uncertainty of urban gas pipeline risk assessment, but for the same object, the risk level of the linear measurement model in $4 \#$ pipeline is lower than other measurement functions, and the risk level of sinusoidal measurement model in $8 \#$ pipeline is higher than other measurement functions. Therefore, considering the evaluation results under different measure functions and focusing on monitoring objects with different results is necessary when using unascertained measure theory for risk assessment. The conclusions obtained from this study clarify the application conditions of unascertained measure theory in urban gas pipeline risk assessment, which helps to reduce the uncertainty in the assessment process and improve the accuracy of the assessment results.
\end{abstract}

Keywords: credible degree recognition criteria; risk assessment; unascertained measure; unknown measure function; urban gas pipeline

\section{INTRODUCTION}

Natural gas is of great significance to the economic development and environmental protection of all countries. However, natural gas is far away from where it is needed, thus usually requiring long-distance pipelines for transportation. At present, pipes are aging to varying degrees with the increase of service life [1]. Gas pipeline is the most important mode of natural gas transportation [2], and it has become an important part of urban facilities and resources due to the characteristics of quick, convenient, economical, and reliable. China's natural gas pipeline has developed rapidly. As early as 1964, China built the first gas pipeline, which is also the beginning of the application of gas pipeline in the country. Through more than 50 years of hard work, China's gas pipeline industry has made great achievements. By the end of 2019, China's natural gas pipeline reached $87000 \mathrm{~km}$, and gas transmission can exceed 350 billion cubic meters per year. However, with the rapid construction of gas pipe network and the aging of some pipelines, safety problems in gas pipeline systems have become increasingly prominent.

Gas pipeline is easily affected by environmental change, external force damage, and other factors in normal operation. As a result, there are varying degrees of pipe wall thinning, cracks and other defects. Besides, the ground conditions of urban buried pipeline network area are increasingly complex, the population density is large, and the influence of human factors is increasing, which leads to gas leakage or burst accidents from time to time. Some accidents even caused huge economic losses, casualties, environmental pollution, and other disastrous consequences, seriously affecting social stability.

Several risk factors threaten the safety of urban gas pipelines, and the surrounding environment of the pipeline is complex and diverse. To ensure the stable and reliable operation of the pipelines and prevent accidents, research on the risk assessment of urban gas pipeline must be carried out. Risk assessment is an important technology of gas pipeline risk control. Common safety risk assessment methods include expert scoring method, Delphi method,
Analytic Hierarchy Process (AHP), fuzzy comprehensive evaluation method, fault tree analysis method, gray comprehensive evaluation method, support vector machine method, TOPSIS (Technique for Order Preference by Similarity to an Ideal Solution) method, and artificial neural network method. Therefore, this study attempts to use unascertained measurement theory to establish measurement models based on different unknown measurement functions to evaluate the risk of urban gas pipeline and reduce the impact of uncertainty on the risk assessment results.

\section{LITERATURE REVIEW}

After World War II, the chemical, aerospace, petroleum, and nuclear industries began to develop rapidly [3]. Since the 1960s, the United States has applied safety research results to construction enterprises and projects, resulting in a significant decline in the average accident rate in the construction industry. In 1975, the Nuclear Regulatory Commission developed and established a wellknown probabilistic risk assessment method, which became a milestone in the history of engineering risk analysis. Akhtar [4] presented a fuzzy fault tree analysis technique for reliability evaluation of the wind energy system, combined the operational failures effect and the errors in the fuzzy environment for the wind energy system configuration. Akyuz [5] focused on conducting a quantitative risk analysis for cargo liquefaction on-board dry bulk ships to enhance the safety in maritime the industry, providing a methodological extension of fuzzy logic into the bow-tie analysis. Suh [6] investigated a reasonable fuzzy logic model (FLM) for quantifying the likelihood of decision-making actions to be used in the human reliability analysis (HRA) of actions required for Level 2 probabilistic safety assessment (PSA). Bakhat [7] proposed a novel systematic approach that combines Multicriteria Decision-Making (MCDM) techniques and Failure Mode Effects and Criticality Analysis (FMECA) tool to reveal the fatal failures and optimize the maintenance actions. Ganbat [8] formulated six steps of reviews in connection with ICP (International Construction 
Projects) risks, BIM (Building information modelling)related risks, risk analysis and management techniques, and BIM uses. Munoz [9] determined a biomechanical risk analysis method based on a multi-methodological study for high-buildings under construction. Marhavillas [10] presented new quantitative risk assessment technique could help safety managers to predict unsafe conditions and prevent fatal accidents. Li [11] based on meta-action failure modes, proposed a risk assessment and ranking method based on cloud model. Esmaeili $[12,13]$ presented an attribute-based risk identification and analysis method and tested the validity of using these fundamental risk attributes to predict safety outcomes. Ning [14] developed a quantitative safety risk assessment model to help site managers evaluate different site layout scenarios accurately and holistically. Huang [15] proposed an improved AHP-gray model that can better reflect the actual safety condition of construction. Gebrehiwet [16] presented an approach for evaluating the risks in case of schedule delays at the various lifecycles of construction projects that can evaluate the typical risk of the schedule delay. Leśniak [17] presented one of the available methodologies for creating risk management strategies using a standard algorithm that includes risk identification, analysis, and assessment. Dong [18] proposed a mine safety risk ranking and grading evaluation model based on the fuzzy-gray correlation method. Artificial neural network [19-22] is referenced as one of the most powerful tools that have been applied to all aspects of life, including fault diagnosis, trend prediction, and residual life analysis, among others. The consequence of pipeline failure can be modelled using computational fluid dynamics, and the probability of failure may be obtained through fault tree analysis or Bayesian approach [23]. Wei [24] calculated the failure probability of gas pipelines by using data from the EGIG (European Gas pipeline Incident data Group) database. However, even a perfect database does not contain all types of accidents.

The above discussion shows that many factors affect safety risks during gas pipeline risk assessment, and complexities and uncertainties abound. However, existing assessment methods cannot be used to deal with uncertainties. Therefore, the key and difficult point of scientific evaluation is seeking systematic and reasonable mathematical methods to analyse and deal with various uncertainty problems during safety risk assessment.

Uncertain information, along with its mathematical processing theory, was first proposed by Wang [25] in 1990. It is new uncertain information different from fuzzy information, random information, and gray information. Basing on this information, Liu [26] established unascertained measure theory and applied it to social and natural sciences. In the applied research of unascertained mathematics, the application of the unascertained measure evaluation model has achieved the most results [26-29]. Aiming at the uncertainty problem of the multi-factor evaluation system and the subjective misjudgement defect of the index weight distribution, some scholars have proposed a comprehensive evaluation method for multifactor indicators using unascertained measure theory. The theory is widely adopted in social development evaluation [30], bid quotation [31], project delivery [32], water and mud inrush in tunnel construction [33], blastability of rock mass [34], rock burst tendency in tunnel [35], geological structural surface evaluation [36], coal seam floor water inrush [37], and so on and achieved good results.
The four types of unknown measure functions constructed using unascertained measure theory are linear, parabolic, exponential, and sinusoidal. Among them, the linear unascertained measure function is simple in structure, convenient in calculation, and widely used. Few scholars have studied the influence of constructing different unascertained measure functions on the evaluation results.

The remainder of this study is organized as follows: Section 3 describes the unascertained measure theory, the method for constructing unascertained measure function, the establishment of evaluation factor space and division of index risk level, the determination of evaluation factors and weights of evaluation indicators, the establishment of risk evaluation model based on unascertained measure, and adopts the gas pipeline evaluation index system established by literature [38] and the measured data of gas pipelines to analysis. Section 4 presents the results analysis. Section 5 draws the conclusions obtained from this study.

\section{METHODOLOGY}

\subsection{Unascertained Measure Theory}

Suppose $a_{1}, a_{2}, \cdots, a_{n}$ are the $n$ factors in the evaluation space $A$, then the evaluation space can be written as $A=\left\{a_{1}, a_{2}, \cdots, a_{n}\right\}$. For any evaluation factor $a_{i}(i=1,2, \cdots, n)$, if there are $m$ indicators to evaluate it, then the evaluation index space $B$ of the evaluation factor $a_{i}$ is a collection of these $m$ indicators, namely, $B=\left\{b_{1}, b_{2}, \cdots, b_{m}\right\}$. If $a_{i j}$ is used to represent the value of the evaluation factor $a_{i}$ on the index $b_{j}(j=1,2, \cdots, m)$, then $a_{i}$ can be expressed as an $m$ dimensional vector $a_{i}=\left\{a_{i 1}, a_{i 2}, \cdots, a_{i m}\right\}$.

Suppose $C_{1}, C_{2}, \cdots, C_{p}$ are the $p$ evaluation levels of any sub-item $a_{i j}$ of $a_{i}$, then the evaluation space $C$ can be written as $C=\left(C_{1}, C_{2}, \cdots, C_{p}\right)$. For the $k^{\text {th }}$ evaluation level $C_{k}$, if it is higher than $C_{k+1}$, then it is recorded as $C_{k}>C_{k+1}$; otherwise, it is recorded as $C_{k}<C_{k+1}$. If $C_{1}>C_{2}>\cdots>C_{p}$ or $C_{1}<C_{2}<\cdots<C_{p}$ is satisfied, then $\left\{C_{1}, C_{2}, \cdots, C_{p}\right\}$ is called the ordered partition class of the evaluation space $C$ [39].

The value $a_{i j}$ belongs to the degree of the $k^{\text {th }}$ evaluation level $C_{k}$, recorded as $\omega_{i j k}=\omega\left(a_{i j} \in C_{k}\right) . \omega$ should meet the following conditions: $0 \leq \omega\left(a_{i j} \in C_{k}\right) \leq 1$, which indicates that a certain number on the interval $[0,1]$ describes the degree to which the value $a_{i j}$ belongs to the evaluation level $C_{k}$; (2) $\omega\left(a_{i j} \in C_{k}\right)=1$, which indicates that $\omega$ satisfies the "normalization" condition with respect to the evaluation space $C$; and (3) $\omega\left(a_{i j} \in \bigcup_{l=1}^{k} C_{l}\right)=\sum_{l=1}^{k} \omega\left(a_{i j} \in C_{k}\right)$, which indicates that $\omega$ satisfies the additivity condition regarding evaluation space $C$. Among them, $i=1,2, \cdots, n, j=1,2, \cdots, m$, $k=1,2, \cdots, p$. The $\omega$ that satisfies the above three 
conditions is called an uncertainty measure or measure for short.

\subsection{Method for Constructing Unascertained Measure Function}

Constructing scientific and reasonable unascertained measure function is the key to describe the uncertain state of things by using unascertained measure theory. In solving practical problems using the aforementioned theory, the evaluator should construct the unascertained measure function according to the relevant information of the evaluation object, actual measurement value, and personal experience.

Assuming that the attribute value of the evaluation object is $d_{i}$ in the initial stage, the attribute is in the $i$ state. In changing the attribute value from $d_{i}$ to $d_{i+1}$, the state of the evaluation object attribute also changes. The state of $i$ decreases, whereas the state of $i+1$ increases. Specifically, when the attribute value of the evaluation object becomes $d_{i+1}$, the $i$ state of the evaluation object property disappears completely to 0 , whereas the $i+1$ state of the attribute increases to 1 . The form of unascertained measure reflects the change of attribute state of evaluation object, and the evaluator should construct the corresponding unascertained measure function according to the intensity of state change of evaluation object. The four common distributions of unascertained measure functions are linear, parabolic, exponential, and sinusoidal distributions. The concrete figure and function expression are shown in Tab. 1.

\begin{tabular}{|c|c|c|}
\hline Distribution form & Graphics & Function Expression \\
\hline Linear distribution & ${ }_{d_{i}}^{1} \sum_{d_{i+1}}^{\mathrm{A}}$ & $\left\{\begin{array}{l}\omega_{i}(x)=\left\{\begin{array}{cc}\frac{-x}{d_{i+1}-d_{i}}+\frac{d_{i+1}}{d_{i+1}-d_{i}} & d_{i}<x \leq d_{i+1} \\
0 & d_{i+1}<x\end{array}\right. \\
\omega_{i+1}(x)=\left\{\begin{array}{cc}\frac{x}{d_{i+1}-d_{i}}+\frac{-d_{i+1}}{d_{i+1}-d_{i}} & d_{i}<x \leq d_{i+1} \\
0 & x \leq d_{i}\end{array}\right.\end{array}\right.$ \\
\hline Parabolic distribution & $\underbrace{}_{d_{i} / \mathrm{d}_{i+1}}$ & $\begin{array}{l}\omega_{i}(x)=\left\{\begin{array}{cc}1-\left(\frac{x-d_{i}}{d_{i+1}-d_{i}}\right)^{2} & d_{i}<x \leq d_{i+1} \\
0 & d_{i+1}<x\end{array}\right. \\
\omega_{i+1}(x)=\left\{\begin{array}{cc}0 & x \leq d_{i} \\
\left(\frac{x-d_{i}}{d_{i+1}-d_{i}}\right)^{2} & d_{i}<x \leq d_{i+1}\end{array}\right.\end{array}$ \\
\hline Exponential distribution & $\frac{\mathrm{C} /}{d_{i}}$ & $\begin{array}{l}\omega_{i}(x)=\left\{\begin{array}{cc}1-\frac{1-\mathrm{e}^{x-d_{i}}}{1-\mathrm{e}^{a_{i+1}-d_{i}}} & d_{i}<x \leq d_{i+1} \\
0 & d_{i+1}<x\end{array}\right. \\
\omega_{i+1}(x)=\left\{\begin{array}{cc}0 & x \leq d_{i} \\
\frac{1-\mathrm{e}^{x-d_{i}}}{1-\mathrm{e}^{d_{i+1}-d_{i}}} & d_{i}<x \leq d_{i+1}\end{array}\right.\end{array}$ \\
\hline Sinusoidal distribution & \begin{tabular}{c|}
$\mathrm{C} /$ \\
$d_{i}$ \\
$d_{i+1}$
\end{tabular} & 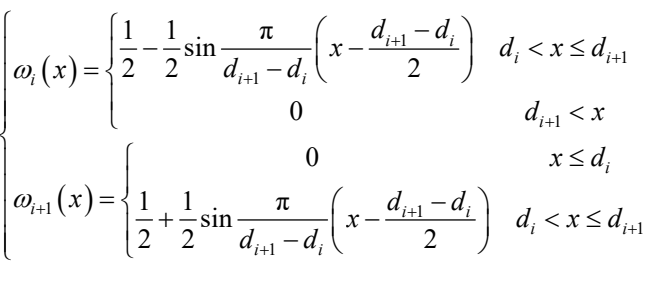 \\
\hline
\end{tabular}

Tab. 1 shows that the value of function expression $\omega_{i}(x)$ in the left interval of $d_{i}$ is 0 , and the image on $\left[d_{i+1}, d_{i+2}\right]$ is consistent with the image of function $\omega_{i+1}(x)$ at $\left(d_{i}, d_{i+1}\right]$. The function $\omega_{i+1}(x)$ is 0 on the left side of $d_{i+1}$, and the function image on interval $\left[d_{i-1}, d_{i}\right]$ is consistent with the function $\omega_{i}(x)$ image on $\left(d_{i}, d_{i+1}\right]$. In any non-zero interval, the measure distribution functions appear in pairs at the same time and satisfy the conditions of non-negativity, normalization, and additivity.

\subsection{Establishment of Evaluation Factor Space and Division of Index Risk Level}

Considering the actual situation of urban gas pipeline and the nature of operational risk, the risk situation is classified into four levels: grade I, low risk; grade II, general risk; grade III, larger risk; and grade IV, significant risk.

Gas pipeline risk evaluation system is an extremely complex system. To achieve reasonable and accurate evaluation, a complete and scientific evaluation index system must be established. Too many evaluation indicators will increase the complexity of the evaluation 
process, and too few evaluation indicators will not fully reflect the objective conditions of the gas pipeline.

In actual engineering, many factors affect the risk of gas pipelines. The comprehensive evaluation index system for gas pipeline risk assessment is composed of three layers including 5 first-level evaluation factors and 34 secondlevel evaluation index (see Tab. 2).

Table 2 Classification table of risk evaluation indexes

\begin{tabular}{|c|c|c|c|c|c|}
\hline $\begin{array}{l}\text { Evaluation } \\
\text { factors }\end{array}$ & Evaluation index & Low risk (1) & General risk (3) & Larger risk (5) & Significant risk (7) \\
\hline \multirow{9}{*}{$\begin{array}{l}\text { Third-party } \\
\text { damage }\end{array}$} & $\begin{array}{l}\text { Pipeline burial depth / } \\
\text { m }\end{array}$ & $\geq 1.2$ & $0.9-1.2$ & $0.6-0.9$ & 0.6 \\
\hline & $\begin{array}{l}\text { Pipeline Line } \\
\text { Identification }\end{array}$ & $\begin{array}{c}\text { No defects or very few } \\
\text { defects }\end{array}$ & Fewer defects & General defect & More defects \\
\hline & $\begin{array}{l}\text { Patrol frequency } \\
\text { (times/months) }\end{array}$ & $\geq 15$ & $10-15$ & $5-10$ & $\leq 5$ \\
\hline & $\begin{array}{l}\text { Inspection staff } \\
\text { responsible }\end{array}$ & Extremely strong & Stronger & General & None \\
\hline & Population density & Unoccupied & Less than 20 households & Residential district & $\begin{array}{c}\text { Business district or } \\
\text { downtown }\end{array}$ \\
\hline & Construction status & $\begin{array}{l}\text { No or very little } \\
\text { construction }\end{array}$ & Less construction & General construction & Frequent construction \\
\hline & Traffic congestion & $\begin{array}{c}\text { No or very few vehicles } \\
\text { pass }\end{array}$ & less vehicles pass & General traffic & Heavy traffic \\
\hline & $\begin{array}{c}\text { Public Pipeline } \\
\text { Protection Awareness }\end{array}$ & Extremely strong & Stronger & General & None \\
\hline & $\begin{array}{c}\text { Gas company } \\
\text { publicity }\end{array}$ & Excellent & Good & General & Poor \\
\hline \multirow{10}{*}{$\begin{array}{l}\text { Corrosion } \\
\text { failure }\end{array}$} & $\begin{array}{l}\text { Type of anticorrosive } \\
\text { coating }\end{array}$ & Three-layer PE & Fused epoxy powder & Coal tar enamel or glass cloth & $\begin{array}{l}\text { No anti-corrosive or } \\
\text { rust-proof paint }\end{array}$ \\
\hline & $\begin{array}{l}\text { Quality of anti- } \\
\text { corrosive coating }\end{array}$ & Excellent & Good & Mediocre & $\mathrm{Bad}$ \\
\hline & Gas corrosive & Pure gas & Trace corrosive impurities & $\begin{array}{l}\text { Small amount of corrosive } \\
\text { impurities }\end{array}$ & $\begin{array}{l}\text { Corrosive impurities } \\
\text { exceeding the standard }\end{array}$ \\
\hline & $\begin{array}{c}\text { Cathodic protection } \\
\text { system }\end{array}$ & $\mathrm{Bad}$ & Mediocre & Good & Excellent \\
\hline & $\begin{array}{l}\text { Years of pipeline } \\
\text { operation }\end{array}$ & $\leq 10$ & $10-15$ & $15-20$ & $\geq 20$ \\
\hline & Soil $\mathrm{pH}$ & $\leq 8.5$ & $6.5-8.5$ & $4.5-6.5$ & $\leq 4.5$ \\
\hline & Soil moisture (\%) & $\leq 10$ & $10-15$ & $15-20$ & $\geq 20$ \\
\hline & Soil salinity (\%) & $\leq 0.1$ & $0.1-0.3$ & $0.3-0.5$ & $\geq 0.5$ \\
\hline & Soil resistivity $(\Omega \cdot \mathrm{m})$ & $\geq 40$ & $25-40$ & $10-25$ & $\leq 10$ \\
\hline & Stress situation & $\begin{array}{c}\text { No or little stress in } \\
\text { pipes }\end{array}$ & Pipe with smaller stress & Stress in piping & $\begin{array}{l}\text { Multiple stresses in } \\
\text { pipes }\end{array}$ \\
\hline \multirow{8}{*}{ Misoperation } & $\begin{array}{l}\text { Design unit and } \\
\text { personnel level }\end{array}$ & $\begin{array}{c}\text { National level } \\
\text { qualification, excellent } \\
\text { design experience } \\
\end{array}$ & $\begin{array}{c}\text { Industry recognition } \\
\text { qualification, good design } \\
\text { experience }\end{array}$ & $\begin{array}{c}\text { Enterprise recognized } \\
\text { qualification, general design } \\
\text { experience }\end{array}$ & $\begin{array}{l}\text { No qualification, } \\
\text { no design experience }\end{array}$ \\
\hline & $\begin{array}{c}\text { Security system } \\
\text { design }\end{array}$ & Excellent & Good & Mediocre & $\mathrm{Bad}$ \\
\hline & $\begin{array}{l}\text { Level of construction } \\
\text { personnel }\end{array}$ & $\begin{array}{l}\text { Excellent skills, } \\
\text { high responsibility, } \\
\text { expert experience }\end{array}$ & $\begin{array}{c}\text { Good skills, } \\
\text { strong responsibility, } \\
\text { advanced experience }\end{array}$ & $\begin{array}{c}\text { Average skills, } \\
\text { intermediate responsibility, } \\
\text { mediocre experience }\end{array}$ & $\begin{array}{l}\text { Low skills, } \\
\text { poor responsibility, } \\
\text { no experience } \\
\end{array}$ \\
\hline & $\begin{array}{l}\text { Construction } \\
\text { supervision }\end{array}$ & $\begin{array}{l}\text { Perfect system and } \\
\text { implement it } \\
\text { conscientiously } \\
\end{array}$ & $\begin{array}{l}\text { Relatively perfect system } \\
\text { and implement it relatively } \\
\text { conscientiously }\end{array}$ & $\begin{array}{l}\text { Construction supervision } \\
\text { system is not perfect or } \\
\text { implemented seriously }\end{array}$ & No regulatory regime \\
\hline & Staff training & $\begin{array}{l}\text { Perfect training } \\
\text { program, strict } \\
\text { implementation }\end{array}$ & $\begin{array}{c}\text { Relatively perfect training } \\
\text { program, good } \\
\text { implementation }\end{array}$ & $\begin{array}{l}\text { Training programs incomplete } \\
\text { or not implemented }\end{array}$ & No training program \\
\hline & Operating procedures & $\begin{array}{l}\text { Perfect, strict } \\
\text { implementation }\end{array}$ & $\begin{array}{l}\text { Relatively perfect, good } \\
\text { implementation }\end{array}$ & $\begin{array}{l}\text { Incomplete or not seriously } \\
\text { implemented }\end{array}$ & $\begin{array}{c}\text { No operating } \\
\text { procedures }\end{array}$ \\
\hline & $\begin{array}{c}\text { Maintenance } \\
\text { personnel level }\end{array}$ & $\begin{array}{l}\text { Excellent skills, } \\
\text { high responsibility, } \\
\text { expert experience }\end{array}$ & $\begin{array}{c}\text { Good skills, } \\
\text { strong responsibility, } \\
\text { advanced experience }\end{array}$ & $\begin{array}{c}\text { Average skills, } \\
\text { intermediate responsibility, } \\
\text { mediocre experience }\end{array}$ & $\begin{array}{l}\text { Low skills, } \\
\text { poor responsibility, } \\
\text { no experience }\end{array}$ \\
\hline & $\begin{array}{l}\text { Maintenance } \\
\text { procedures }\end{array}$ & $\begin{array}{l}\text { Perfect, strict } \\
\text { implementation }\end{array}$ & $\begin{array}{l}\text { Relatively perfect, good } \\
\text { implementation }\end{array}$ & $\begin{array}{l}\text { Incomplete or not seriously } \\
\text { implemented }\end{array}$ & $\begin{array}{l}\text { No operating } \\
\text { procedures }\end{array}$ \\
\hline \multirow{3}{*}{ Pipeline defect } & Pipe situation & $\begin{array}{l}\text { No defects, perfect } \\
\text { mechanical properties }\end{array}$ & $\begin{array}{l}\text { Very few defects, good } \\
\text { mechanical properties }\end{array}$ & $\begin{array}{c}\text { Small number of defects, } \\
\text { generally mechanical } \\
\text { properties }\end{array}$ & $\begin{array}{c}\text { Large number of } \\
\text { defects, poor } \\
\text { mechanical properties }\end{array}$ \\
\hline & Welding & $\begin{array}{l}\text { Perfect quality, high } \\
\text { detection rate }\end{array}$ & $\begin{array}{l}\text { Good quality, relatively } \\
\text { high detection rate }\end{array}$ & $\begin{array}{l}\text { Quality and detection rates in } \\
\text { general }\end{array}$ & $\begin{array}{c}\text { Poor quality, low } \\
\text { detection rate or no } \\
\text { detection } \\
\end{array}$ \\
\hline & $\begin{array}{l}\text { Quality of anti- } \\
\text { corrosion coating }\end{array}$ & Excellent & Good & Mediocre & $\mathrm{Bad}$ \\
\hline \multirow{4}{*}{$\begin{array}{l}\text { Natural } \\
\text { disaster }\end{array}$} & Earthquake & None & Less & More & Frequent \\
\hline & Floods & None & Less & More & Frequent \\
\hline & Soil movement & None & Less & More & Frequent \\
\hline & Other disasters & None & Less & More & Frequent \\
\hline
\end{tabular}


The evaluation index can be divided into two types according to its nature: quantitative index and qualitative index. Qualitative index cannot be directly used in pipeline evaluation because it must be quantified first. Qualitative indexes can be quantified through several ways, including classification standard quantification method, expert investigation method and fuzzy processing method [40]. The classification standard quantification method is widely used because of its simple, convenient, and effective characteristics, so this study uses it to transform the qualitative index into a quantitative one (see Tab. 2).

\subsection{Determination of Evaluation Factors and Weights of Evaluation Indicators}

Weight is a sign describing the importance of the evaluation index in the index system. The methods for calculating weights mainly include empirical weighting method, AHP, principal component analysis method, and entropy weight method. The previous classification of evaluation index grades reveals more qualitative evaluation indexes. AHP can quantify qualitative indicators to reduce the influence of subjective factors and make the evaluation results more scientific and reasonable and in line with objective reality. In this study, AHP is used to calculate the weight.

The main process of AHP is as follows:

(1) Establish the research object hierarchy model.

(2) Construct the judgment matrix.

Based on the risk evaluation index system, assuming the relative importance of the comparative evaluation indexes $x_{i}$ and $x_{j}$ to its upper factor $X$, the 1 to 9 scale method is usually used. This method quantifies the comparison results between indicators and uses numerical values to indicate the relative importance of the two indicators at the lower level relative to the factors at the upper level (see Tab. 3).

Table 3 Scale and meaning of judgment matrix
\begin{tabular}{|l|c|}
\hline \multicolumn{1}{|c|}{ Meaning } & Assignment \\
\hline $\begin{array}{l}\text { Comparing factors } x_{i} \text { and } x_{j} \text {, both have the same } \\
\text { importance. }\end{array}$ & 1 \\
\hline $\begin{array}{l}\text { Comparing factors } x_{i} \text { and } x_{j} \text {, the former is slightly } \\
\text { important than the latter. }\end{array}$ & 5 \\
\hline $\begin{array}{l}\text { Comparing factors } x_{i} \text { and } x_{j} \text {, the former is obviously } \\
\text { important than the latter. }\end{array}$ & 7 \\
\hline $\begin{array}{l}\text { Comparing factors } x_{i} \text { and } x_{j}, \text { the former is more important } \\
\text { than the latter. }\end{array}$ & 9 \\
\hline $\begin{array}{l}\text { Comparing factors } x_{i} \text { and } x_{j}, \text { the former is extremely } \\
\text { more important than the latter. }\end{array}$ & $2,4,6,8$ \\
\hline $\begin{array}{l}\text { The importance of contrasting factors } x_{i} \text { and } x_{j} \text { lies in the } \\
\text { middle of the adjacent judgment. }\end{array}$ & 5 \\
\hline
\end{tabular}

Suppose $g_{i j}$ represents the ratio of the relative importance of $x_{i}$ and $x_{j}$, then the established judgment matrix $G$ is expressed as follows:

$$
G=\left[\begin{array}{cccc}
g_{11} & g_{12} & \cdots & g_{1 n} \\
g_{21} & g_{22} & \cdots & g_{2 n} \\
\vdots & \vdots & \cdots & \vdots \\
g_{n 1} & g_{n 2} & \cdots & g_{n n}
\end{array}\right]
$$

(3) Calculate the weight.

This model uses the sum-product method to solve the weights, and the steps are as follows:

1) Normalize matrix $\boldsymbol{G}$ by column to get matrix $\boldsymbol{H}=\left(h_{i j}\right)_{n \times n}$.

2) Sum matrix $\boldsymbol{G}$ in rows to get vector $\boldsymbol{O}=\left(O_{1}, O_{2}, \ldots, O_{n}\right)^{\mathrm{T}}, O_{i}=\sum_{j=1}^{n} h_{i j} \quad(i=1,2, \cdots, n)$.

3) Normalize vector $\boldsymbol{O}$ to obtain weight vector $\overline{\boldsymbol{O}}$, $\overline{\boldsymbol{O}}=O_{i} / \sum_{i=1}^{n} O_{i}(i=1,2, \ldots, n)$.

4) Matrix $\boldsymbol{H}$, maximum eigenvalue $\lambda_{\max }$, $\lambda_{\max }=\sum_{i=1}^{n}[H \bar{O}]_{i} / n(\bar{O})_{i}(i=1,2, \cdots, n)$.

(4) Inspect consistency.

The judgment matrix $\boldsymbol{H}$ constructed by the scaling method is susceptible to deviations caused by subjective factors. To ensure the accuracy of the weights, the consistency of the matrix $\boldsymbol{H}$ should be verified. The consistency ratio $C R$ is an important criterion to test whether matrix $\boldsymbol{H}$ meets the consistency condition. In $C R$ $=C I / R I, C I$ represents the general consistency index and $R I$ represents the average random consistency index. $C I$ can be obtained by formula $C I=\left(\lambda_{\max }-n\right) /(n-1)$, where $\lambda_{\max }$ is the largest characteristic root of matrix $G$ and $n$ is the matrix order.

$R I$ is an important index to correct the $C I$. Tab. 4 shows the value of $R I$ corresponding to different matrix orders.

Table 4 Comparison table of $R /$ value and order

\begin{tabular}{|l|c|c|c|c|c|c|}
\hline \multicolumn{1}{|c|}{ Order } & 1 & 2 & 3 & 4 & 5 & 6 \\
\hline$R I$ value & 0 & 0 & 0.52 & 0.89 & 1.12 & 1.24 \\
\hline Order & 7 & 8 & 9 & 10 & 11 & 12 \\
\hline$R I$ value & 1.36 & 1.41 & 1.46 & 1.49 & 1.52 & 1.54 \\
\hline
\end{tabular}

When $C R<0.1$, the reconstructed judgment matrix is acceptable. When $C R \geq 0.1$, the reconstructed judgment matrix is unacceptable, 1 and the matrix $\boldsymbol{G}$ must be modified or reconstructed until $C R<0.1$ is satisfied.

Table 5 The weight of first-level factor scale index

\begin{tabular}{|l|c|c|}
\hline \multicolumn{1}{|c|}{ Evaluation factors } & Weight & \multirow{2}{*}{$\lambda_{\max }$} \\
\cline { 1 - 2 } Third-party damage $\left(f_{1}\right)$ & 0.4904 & \\
\cline { 1 - 2 } Corrosion failure $\left(f_{2}\right)$ & 0.2264 & \multirow{2}{*}{5.0988} \\
\cline { 1 - 2 } Misoperation $\left(f_{3}\right)$ & 0.0558 & \\
\cline { 1 - 2 } Pipeline defect $\left(f_{4}\right)$ & 0.1407 & \\
\cline { 1 - 2 } Natural disaster $\left(f_{5}\right)$ & 0.0867 & \\
\hline
\end{tabular}

Table 6 The weight of third-party damage to secondary indicators

\begin{tabular}{|l|l|l|}
\hline \multicolumn{1}{|c|}{ Index } & Weight & $\lambda_{\max }$ \\
\hline Pipeline burial depth $\left(f_{11}\right)$ & 0.2239 & \\
\hline Pipeline Line Identification $\left(f_{12}\right)$ & 0.0507 \\
\cline { 1 - 2 } Patrol frequency $\left(f_{13}\right)$ & 0.0621 \\
\cline { 1 - 2 } Inspection staff responsible $\left(f_{14}\right)$ & 0.0521 & \multirow{3}{*}{9.3526} \\
\cline { 1 - 2 } Population density $\left(f_{15}\right)$ & 0.0824 & 0.2934 \\
\cline { 1 - 2 } Construction status $\left(f_{16}\right)$ & 0.1302 \\
\cline { 1 - 2 } Traffic congestion $\left(f_{17}\right)$ & 0.0757 \\
\cline { 1 - 2 } Public Pipeline Protection Awareness $\left(f_{18}\right)$ & 0.0295 & \\
\hline Gas company publicity $\left(f_{19}\right)$ & \\
\hline
\end{tabular}

Following the basic principle of AHP and considering the actual pipeline situation and statistical accident data, the weight value of each factor and index in the previous 
evaluation index system is calculated. On the basis of firstorder factors in the index system, the 1 to 9 scale method is used to compare them. According to the above process, the weight of each factor's corresponding index is obtained, and the concrete results are shown in Tabs. 5 to 10, where $C R<0.1$.

Table 7 The weight of corrosion failure to secondary indicators

\begin{tabular}{|l|l|l|}
\hline \multicolumn{1}{|c|}{ Index } & Weight & $\lambda_{\max }$ \\
\cline { 1 - 2 } Type of anticorrosive coating $\left(f_{21}\right)$ & 0.1430 & \\
\cline { 1 - 2 } Quality of anti-corrosive coating $\left(f_{22}\right)$ & 0.2046 & \\
\cline { 1 - 2 } Gas corrosive $\left(f_{23}\right)$ & 0.0436 & \\
\cline { 1 - 2 } Cathodic protection system $\left(f_{24}\right)$ & 0.0913 & \multirow{2}{*}{10.245} \\
\cline { 1 - 2 } Years of pipeline operation $\left(f_{25}\right)$ & 0.2832 & \\
\cline { 1 - 2 } Soil pH $\left(f_{26}\right)$ & 0.0304 & \\
\cline { 1 - 2 } Soil moisture $\left(f_{27}\right)$ & 0.0583 & \\
\cline { 1 - 2 } Soil salinity $\left(f_{28}\right)$ & 0.0256 & \\
\cline { 1 - 2 } Soil resistivity $\left(f_{29}\right)$ & 0.0837 & \\
\cline { 1 - 2 } Stress situation $\left(f_{210}\right)$ & 0.0363 & \\
\hline
\end{tabular}

Table 8 The weight of misoperation to secondary indicators

\begin{tabular}{|l|c|c|}
\hline \multicolumn{1}{|c|}{ Index } & Weight & $\lambda_{\max }$ \\
\hline Design unit and personnel level $\left(f_{31}\right)$ & 0.0682 & \\
\cline { 1 - 2 } Security system design $\left(f_{32}\right)$ & 0.0519 & \\
\cline { 1 - 2 } Level of construction personnel $\left(f_{33}\right)$ & 0.2843 & \multirow{2}{*}{8.1785} \\
\cline { 1 - 2 } Construction supervision $\left(f_{34}\right)$ & 0.2103 & \\
\cline { 1 - 2 } Staff training $\left(f_{35}\right)$ & 0.0342 & \\
\cline { 1 - 2 } Operating procedures $\left(f_{36}\right)$ & 0.0649 & \\
\cline { 1 - 2 } Maintenance personnel level $\left(f_{37}\right)$ & 0.1585 & \\
\cline { 1 - 2 } Maintenance procedures $\left(f_{38}\right)$ & 0.1277 & \\
\hline
\end{tabular}

Table 9 The weight of pipeline defect to secondary indicators

\begin{tabular}{|l|c|c|}
\hline \multicolumn{1}{|c|}{ Index } & Weight & $\lambda_{\max }$ \\
\cline { 1 - 2 } Pipe situation $\left(f_{41}\right)$ & 0.1095 & \multirow{3}{*}{3.0037} \\
\cline { 1 - 2 } Welding $\left(f_{42}\right)$ & 0.5815 & \\
\cline { 1 - 2 } Quality of anti-corrosion coating $\left(f_{43}\right)$ & 0.3090 & \\
\hline
\end{tabular}

Table 10 The weight of natural disaster to secondary indicators

\begin{tabular}{|l|c|c|}
\hline \multicolumn{1}{|c|}{ Index } & Weight & $\lambda_{\max }$ \\
\hline Earthquake $\left(f_{51}\right)$ & 0.1643 & \\
\cline { 1 - 2 } Floods $\left(f_{52}\right)$ & 0.2781 & \multirow{2}{*}{4.0606} \\
\cline { 1 - 2 } Soil movement $\left(f_{53}\right)$ & 0.3951 & \\
\cline { 1 - 2 } Other disasters $\left(f_{54}\right)$ & 0.1634 & \\
\hline
\end{tabular}

\subsection{Establishment of Risk Evaluation Model Based on Unascertained Measure}

(1) Classification of unascertained measure function of evaluation index

For some quantitative indexes in the gas pipeline risk assessment model, the higher the value, the higher the risk level. For other indexes, the smaller the value, the higher the risk level. The index in which the risk level increases with the increase of the value is called the maximum index; otherwise, it is the extremely small index. When constructing the unascertained measure function, the evaluator should determine the corresponding measure function according to the change of index risk level with the value.

Maximum index: $\begin{cases}x_{i}=C_{1} & 0<x<a \\ x_{i}=C_{2} & a \leq x<b \\ x_{i}=C_{3} & b \leq x<c \\ x_{i}=C_{4} & c \leq x\end{cases}$
Extremely small index: $\begin{cases}x_{j}=C_{1} & c<x \\ x_{j}=C_{2} & b \leq x<c \\ x_{j}=C_{3} & a \leq x<b \\ x_{j}=C_{4} & 0<x \leq a\end{cases}$

where $x_{i}$ and $x_{j}$ respectively represent extremely large and extremely small quantitative indicators, $x$ is the value of the indicator, and $C_{1}, C_{2}, C_{3}$, and $C_{4}$ are the four risk levels.

(2) Structure of single index unascertained measure model

There are $m$ indicators $\left\{f_{i 1}, f_{i 2}, \cdots, f_{i m}\right\}$ for factor $F_{i}$ in factor space $F=\left\{F_{1}, F_{2}, F_{3}\right\}$ to evaluate it. According to the evaluation index classification table (Tab. 2), the corresponding measure function $\omega\left(a_{i j} \in C_{k}\right)$ $(i=1,2,3, j=1,2, \cdots, m, k=1,2,3,4)$ of each index is constructed, and the index value is determined according to the actual situation of the urban gas pipeline. The index measure vector is then obtained, and the single index measure matrix $\boldsymbol{P}$ of factor $X_{i}$ is established.

$$
\boldsymbol{P}_{i}=\left(\omega_{i j k}\right)_{m \times 4}=\left[\begin{array}{cccc}
\omega_{i 11} & \omega_{i 12} & \omega_{i 13} & \omega_{i 14} \\
\omega_{i 21} & \omega_{i 22} & \omega_{i 23} & \omega_{i 24} \\
\vdots & \vdots & \vdots & \vdots \\
\omega_{i m 1} & \omega_{i m 2} & \omega_{i m 3} & \omega_{i m 4}
\end{array}\right]
$$

(3) Construction of multi-indicator integrated unascertained measure model

Using AHP to determine the weight of each index, combined with the single index measure matrix $\boldsymbol{P}_{i}$, the single factor measure vector $\boldsymbol{Q}_{i}$ of evaluation factor $F_{i}$ is calculated as follows:

$$
\boldsymbol{Q}_{i}=\boldsymbol{O}_{i} \cdot \boldsymbol{P}_{i}=\left[\begin{array}{llll}
\omega_{i 1} & \omega_{i 2} & \omega_{i 3} & \omega_{i 4}
\end{array}\right]
$$

where $\boldsymbol{O}_{i}$ is the weight vector of each indicator of factor $F_{i}$.

The multi-index comprehensive measurement matrix composed of all risk assessment factors of urban gas pipeline is given as follows:

$\boldsymbol{Q}=\left[\begin{array}{l}Q_{1} \\ Q_{2} \\ Q_{3}\end{array}\right]=\left[\begin{array}{llll}\omega_{11} & \omega_{12} & \omega_{13} & \omega_{14} \\ \omega_{21} & \omega_{22} & \omega_{23} & \omega_{24} \\ \omega_{31} & \omega_{32} & \omega_{33} & \omega_{34}\end{array}\right]$

The measure vectors of evaluation objects are expressed as follows:

$$
\boldsymbol{\mu}=\boldsymbol{O} \cdot \boldsymbol{Q}=\left[\begin{array}{llll}
\omega_{1} & \omega_{2} & \omega_{3} & \omega_{4}
\end{array}\right]
$$

where $\boldsymbol{O}$ is the weight vector of the evaluation factors in the criterion layer.

(4) Confidence degree to identify risk level

The classification of evaluation grade is ordered as $C_{1}<C_{2}<C_{3}<C_{4}$, and the risk level of the system increases with the increase of grade. Combined with the 
concept of unascertained measure, $\left\{C_{1}, C_{2}, C_{3}, C_{4}\right\}$ is an ordered segmentation class of evaluation space $C$. For ordered space, the maximum membership criterion is no longer applicable, and the risk level should be determined according to the confidence criterion. If the confidence level is set at $\lambda=0.7, k=\min \left|k: \sum_{i=1}^{k} \omega_{i} \geq \lambda,(k=1,2,3,4)\right|$ then the risk level of the evaluation object is at the $k^{\text {th }}$ level $C_{k}$.

\section{RESULTS ANALYSIS}

According to the classification standard of each evaluation index established above, the value of each index is determined by investigating the relevant technical data of pipeline and combining with expert experience, as shown in Tab. 11.

Table 11 Evaluation index value table of each pipe section

\begin{tabular}{|c|c|c|c|c|c|c|c|c|c|c|c|}
\hline \multirow{2}{*}{ Evaluation factors } & \multirow{2}{*}{ Evaluation index } & \multicolumn{10}{|c|}{ Index value of each pipe section } \\
\hline & & $1 \#$ & $2 \#$ & $3 \#$ & $4 \#$ & $5 \#$ & $6 \#$ & $7 \#$ & $8 \#$ & $9 \#$ & $10 \#$ \\
\hline \multirow{9}{*}{ Third-party damage } & Pipeline burial depth / $\mathrm{m}$ & 1.1 & 1.1 & 1.2 & 1.2 & 1.2 & 1.3 & 1.3 & 1.1 & 13 & 1.3 \\
\hline & Pipeline Line Identification & 2 & 1 & 3 & 3 & 3 & 1 & 1 & 3 & 3 & 2 \\
\hline & Patrol frequency / times/months & 30 & 30 & 30 & 30 & 30 & 30 & 30 & 30 & 30 & 30 \\
\hline & Inspection staff responsible & 2 & 2 & 2 & 2 & 2 & 2 & 2 & 2 & 2 & 2 \\
\hline & Population density & 3 & 4 & 6 & 5 & 4 & 3 & 3 & 6 & 6 & 5 \\
\hline & Construction status & 5 & 2 & 2 & 4 & 2 & 4 & 4 & 4 & 3 & 3 \\
\hline & Traffic congestion & 2 & 3 & 6 & 5 & 6 & 3 & 4 & 7 & 6 & 3 \\
\hline & Public Pipeline Protection Awareness & 3 & 6 & 5 & 3 & 3 & 3 & 5 & 5 & 4 & 3 \\
\hline & Gas company publicity & 4 & 4 & 4 & 4 & 4 & 4 & 4 & 4 & 4 & 4 \\
\hline \multirow{10}{*}{ Corrosion failure } & Type of anticorrosive coating & 1 & 1 & 1 & 3 & 3 & 1 & 1 & 3 & 3 & 1 \\
\hline & Quality of anti-corrosive coating & 2 & 2 & 5 & 5 & 4 & 2 & 3 & 5 & 5 & 4 \\
\hline & Gas corrosive & 3 & 3 & 3 & 3 & 3 & 3 & 3 & 3 & 3 & 3 \\
\hline & Cathodic protection system & 4 & 2 & 4 & 6 & 4 & 2 & 2 & 5 & 6 & 5 \\
\hline & Years of pipeline operation & 8 & 8 & 12 & 15 & 15 & 6 & 8 & 15 & 15 & 10 \\
\hline & Soil pH & 9.8 & 8.6 & 8.3 & 9.5 & 8 & 9.8 & 8.7 & 10 & 8.5 & 8.5 \\
\hline & Soil moisture / \% & 14.3 & 9.8 & 8.5 & 10.3 & 12.4 & 13.8 & 18.6 & 115 & 6.5 & 20.6 \\
\hline & Soil salinity / \% & 0.31 & 0.05 & 0.11 & 0.08 & 0.21 & 0.43 & 0.19 & 0.29 & 0.02 & 0.15 \\
\hline & Soil resistivity $/ \Omega \cdot \mathrm{m}$ & 3.29 & 29.8 & 45.8 & 28.4 & 20.2 & 2.01 & 19.9 & 3.04 & 75.1 & 32.3 \\
\hline & \begin{tabular}{|l|} 
Stress situation \\
\end{tabular} & 5 & 3 & 2 & 4 & 2 & 3 & 3 & 2 & 3 & 4 \\
\hline \multirow{8}{*}{ Misoperation } & Design unit and personnel level & 1 & 1 & 3 & 3 & 3 & 1 & 1 & 3 & 3 & 3 \\
\hline & Security system design & 2 & 3 & 3 & 5 & 4 & 3 & 3 & 4 & 5 & 3 \\
\hline & Level of construction personnel & 1 & 2 & 2 & 3 & 3 & 1 & 2 & 3 & 4 & 2 \\
\hline & Construction supervision & 2 & 3 & 3 & 3 & 2 & 3 & 3 & 3 & 3 & 4 \\
\hline & Staff training & 3 & 3 & 3 & 3 & 3 & 3 & 3 & 3 & 3 & 3 \\
\hline & Operating procedures & 3 & 3 & 3 & 3 & 3 & 3 & 3 & 3 & 3 & 3 \\
\hline & Maintenance personnel level & 2 & 2 & 2 & 2 & 2 & 2 & 2 & 2 & 2 & 2 \\
\hline & Maintenance procedures & 3 & 3 & 3 & 3 & 3 & 3 & 3 & 3 & 3 & 3 \\
\hline \multirow{3}{*}{ Pipeline defect } & Pipe situation & 1 & 1 & 2 & 5 & 4 & 1 & 2 & 6 & 4 & 1 \\
\hline & Welding & 1 & 2 & 3 & 3 & 3 & 1 & 2 & 4 & 3 & 3 \\
\hline & Quality of anti-corrosion coating & 2 & 3 & 2 & 4 & 4 & 2 & 4 & 3 & 2 & 3 \\
\hline \multirow{4}{*}{ natural disaster } & \begin{tabular}{|l} 
Earthquake \\
\end{tabular} & 2 & 2 & 2 & 2 & 2 & 2 & 2 & 2 & 2 & 2 \\
\hline & \begin{tabular}{|l|} 
Floods \\
\end{tabular} & 1 & 1 & 2 & 2 & 1 & 1 & 3 & 2 & 1 & 1 \\
\hline & \begin{tabular}{|l|} 
Soil movement \\
\end{tabular} & 4 & 5 & 3 & 4 & 3 & 4 & 2 & 2 & 2 & 5 \\
\hline & Other disasters & 2 & 1 & 2 & 3 & 2 & 1 & 2 & 1 & 1 & 2 \\
\hline
\end{tabular}

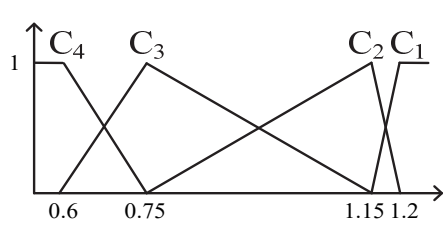

a) Linear

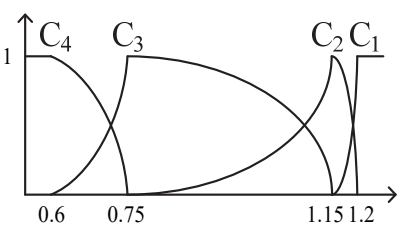

b) Parabolic

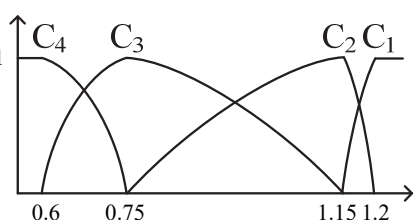

c) Exponential

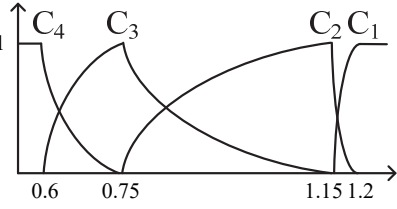

d) Sinusoidal

Figure 4 Quantitative index: pipeline burial depth measurement function

According to the classification standard of the index in Tab. 2, the measure function of each index is constructed, the index value is determined according to the actual situation, the measure vector is obtained, and the unascertained measure matrix of each index is established. The index contains quantitative and qualitative indexes, so the measure function is established by taking the pipeline burial depth in the quantitative index and the pipeline line identification in the qualitative index as an example.
According to the confidence criterion, the risk evaluation results of each section under different measure functions are judged,

$$
k=\min \left|k: \sum_{i=1}^{k} \omega_{i} \geq \lambda,(k=1,2,3,4)\right|, \lambda=0.7 \text {. }
$$

If $\omega_{1}+\omega_{2} \geq 0.7$, then the pipe section is at the second risk level. If $\omega_{1}+\omega_{2} \geq 0.7$ and $\omega_{1}+\omega_{2}+\omega_{3} \geq 0.7$, then the pipe section is at the third risk level $C_{3}$. The risk evaluation results of each pipe section under different 
unascertained measure functions are obtained, as shown in Tab. 12.

Let $\lambda=0.7$. The evaluation results of $4 \#$ and $8 \#$ pipe sections are inconsistent. The risk level of the risk evaluation model constructed by the linear distribution measure function is III, and the evaluation result is higher than that of the other three measure functions. The risk level of the risk evaluation model constructed by the exponential distribution measure function is II, and the evaluation result is lower than that constructed by the other three measure functions.

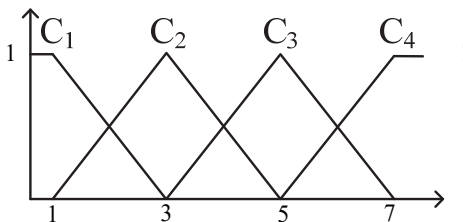

a) Linear

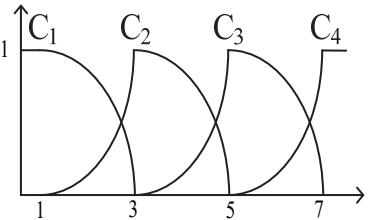

b) Parabolic

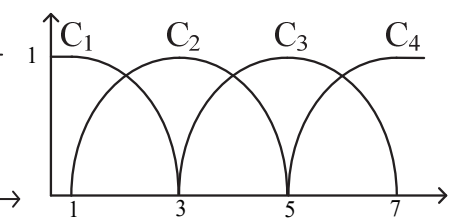

c) Exponential

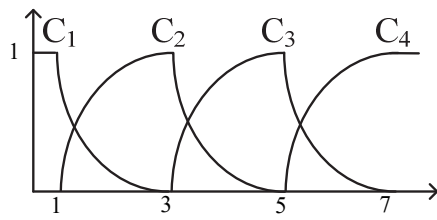

d) Sinusoidal

Figure 5 Qualitative index: pipeline line identification measurement function

Table 12 Results of risk assessment for each section of a pipe with different unascertained measure functions

\begin{tabular}{|c|c|c|c|c|c|c|c|c|c|c|c|c|c|}
\hline \multirow{2}{*}{$\begin{array}{c}\text { Pipe } \\
\text { section } \\
\text { number }\end{array}$} & \multirow{2}{*}{$\begin{array}{l}\text { Measure } \\
\text { function type }\end{array}$} & \multicolumn{4}{|c|}{$\begin{array}{l}\text { Multi-index comprehensive } \\
\text { measure }\end{array}$} & \multirow{2}{*}{$\begin{array}{c}\text { Risk level } \\
\lambda=0.7\end{array}$} & \multirow{2}{*}{$\begin{array}{c}\text { Pipe } \\
\text { section } \\
\text { number }\end{array}$} & \multirow{2}{*}{$\begin{array}{l}\text { Measure } \\
\text { function type }\end{array}$} & \multicolumn{4}{|c|}{$\begin{array}{l}\text { Multi-index comprehensive } \\
\text { measure }\end{array}$} & \multirow{2}{*}{$\begin{array}{c}\text { Risk level } \\
\lambda=0.7\end{array}$} \\
\hline & & $\lambda_{1}$ & $\lambda_{2}$ & $\lambda_{3}$ & $\lambda_{4}$ & & & & $\lambda_{1}$ & $\lambda_{2}$ & $\lambda_{3}$ & $\lambda_{4}$ & \\
\hline \multirow{4}{*}{$1 \#$} & $\begin{array}{c}\text { Linear } \\
\text { distribution }\end{array}$ & 0.42 & 0.48 & 0.08 & 0.02 & II & \multirow{4}{*}{$6 \#$} & $\begin{array}{c}\text { Linear } \\
\text { distribution }\end{array}$ & 0.47 & 0.4 & 0.1 & 0.02 & II \\
\hline & $\begin{array}{c}\text { Parabolic } \\
\text { distribution }\end{array}$ & 0.48 & 0.42 & 0.08 & 0.01 & II & & $\begin{array}{c}\text { Parabolic } \\
\text { distribution }\end{array}$ & 0.51 & 0.41 & 0.05 & 0.02 & II \\
\hline & $\begin{array}{l}\text { Exponential } \\
\text { distribution }\end{array}$ & 0.5 & 0.4 & 0.09 & 0.01 & II & & $\begin{array}{l}\text { Exponential } \\
\text { distribution }\end{array}$ & 0.51 & 0.41 & 0.06 & 0.02 & II \\
\hline & $\begin{array}{l}\text { Sinusoidal } \\
\text { distribution }\end{array}$ & 0.36 & 0.56 & 0.04 & 0.04 & II & & $\begin{array}{l}\text { Sinusoidal } \\
\text { distribution }\end{array}$ & 0.38 & 0.59 & 0.02 & 0.02 & II \\
\hline \multirow{4}{*}{$2 \#$} & $\begin{array}{c}\text { Linear } \\
\text { distribution }\end{array}$ & 0.35 & 0.44 & 0.15 & 0.05 & II & \multirow{4}{*}{ 7\# } & $\begin{array}{c}\text { Linear } \\
\text { distribution }\end{array}$ & 0.39 & 0.41 & 0.19 & 0.01 & II \\
\hline & $\begin{array}{c}\text { Parabolic } \\
\text { distribution }\end{array}$ & 0.44 & 0.36 & 0.17 & 0.03 & II & & $\begin{array}{c}\text { Parabolic } \\
\text { distribution }\end{array}$ & 0.45 & 0.42 & 0.13 & 0 & II \\
\hline & $\begin{array}{l}\text { Exponential } \\
\text { distribution }\end{array}$ & 0.44 & 0.36 & 0.17 & 0.03 & II & & $\begin{array}{l}\text { Exponential } \\
\text { distribution }\end{array}$ & 0.44 & 0.42 & 0.14 & 0 & II \\
\hline & $\begin{array}{c}\text { Sinusoidal } \\
\text { distribution }\end{array}$ & 0.16 & 0.69 & 0.04 & 0.1 & II & & $\begin{array}{c}\text { Sinusoidal } \\
\text { distribution }\end{array}$ & 0.36 & 0.58 & 0.03 & 0.01 & II \\
\hline \multirow{4}{*}{$3 \#$} & $\begin{array}{c}\text { Linear } \\
\text { distribution }\end{array}$ & 0.35 & 0.44 & 0.15 & 0.05 & II & \multirow{4}{*}{$8 \#$} & $\begin{array}{c}\text { Linear } \\
\text { distribution }\end{array}$ & 0.11 & 0.49 & 0.29 & 0.11 & III \\
\hline & $\begin{array}{c}\text { Parabolic } \\
\text { distribution }\end{array}$ & 0.44 & 0.36 & 0.17 & 0.03 & II & & $\begin{array}{c}\text { Parabolic } \\
\text { distribution }\end{array}$ & 0.12 & 0.56 & 0.22 & 0.1 & III \\
\hline & $\begin{array}{l}\text { Exponential } \\
\text { distribution }\end{array}$ & 0.44 & 0.36 & 0.17 & 0.03 & II & & $\begin{array}{c}\text { Exponential } \\
\text { distribution }\end{array}$ & 0.14 & 0.54 & 0.22 & 0.1 & III \\
\hline & $\begin{array}{l}\text { Sinusoidal } \\
\text { distribution }\end{array}$ & 0.16 & 0.69 & 0.04 & 0.1 & II & & $\begin{array}{l}\text { Sinusoidal } \\
\text { distribution }\end{array}$ & 0.18 & 0.56 & 0.15 & 0.11 & II \\
\hline \multirow{4}{*}{ 4\# } & $\begin{array}{c}\text { Linear } \\
\text { distribution }\end{array}$ & 0.17 & 0.48 & 0.34 & 0.01 & III & \multirow{4}{*}{ 9\# } & $\begin{array}{c}\text { Linear } \\
\text { distribution }\end{array}$ & 0.29 & 0.5 & 0.15 & 0.06 & II \\
\hline & $\begin{array}{c}\text { Parabolic } \\
\text { distribution }\end{array}$ & 0.19 & 0.53 & 0.27 & 0.01 & II & & $\begin{array}{c}\text { Parabolic } \\
\text { distribution }\end{array}$ & 0.32 & 0.49 & 0.16 & 0.03 & II \\
\hline & $\begin{array}{l}\text { Exponential } \\
\text { distribution }\end{array}$ & 0.19 & 0.53 & 0.27 & 0.01 & II & & $\begin{array}{l}\text { Exponential } \\
\text { distribution }\end{array}$ & 0.32 & 0.49 & 0.16 & 0.03 & II \\
\hline & $\begin{array}{c}\text { Sinusoidal } \\
\text { distribution }\end{array}$ & 0.15 & 0.66 & 0.17 & 0.02 & II & & $\begin{array}{c}\text { Sinusoidal } \\
\text { distribution }\end{array}$ & 0.38 & 0.47 & 0.02 & 0.12 & II \\
\hline \multirow{4}{*}{$5 \#$} & $\begin{array}{c}\text { Linear } \\
\text { distribution }\end{array}$ & 0.28 & 0.5 & 0.19 & 0.03 & II & \multirow{4}{*}{$10 \#$} & $\begin{array}{c}\text { Linear } \\
\text { distribution }\end{array}$ & 0.28 & 0.56 & 0.16 & 0 & II \\
\hline & $\begin{array}{c}\text { Parabolic } \\
\text { distribution }\end{array}$ & 0.34 & 0.51 & 0.14 & 0.02 & II & & $\begin{array}{c}\text { Parabolic } \\
\text { distribution }\end{array}$ & 0.31 & 0.56 & 0.13 & 0 & II \\
\hline & $\begin{array}{l}\text { Exponential } \\
\text { distribution }\end{array}$ & 0.33 & 0.52 & 0.13 & 0.02 & II & & $\begin{array}{l}\text { Exponential } \\
\text { distribution }\end{array}$ & 0.3 & 0.58 & 0.12 & 0 & II \\
\hline & $\begin{array}{l}\text { Sinusoidal } \\
\text { distribution }\end{array}$ & 0.16 & 0.7 & 0.08 & 0.06 & II & & $\begin{array}{l}\text { Sinusoidal } \\
\text { distribution }\end{array}$ & 0.41 & 0.48 & 0.11 & 0 & II \\
\hline
\end{tabular}

The risk evaluation model constructed by different measure functions may not be consistent with the evaluation results of the same object. When unascertained measure theory is used to establish the unascertained measure function of each index, the analysis results vary when the comprehensive evaluation is carried out. Therefore, when using the aforementioned theory for comprehensive evaluation, the evaluation results under different measure functions should be considered, and the focus must be on monitoring the objects with different results.

\section{CONCLUSIONS}

The occurrence of urban gas pipeline accidents is affected by many factors. Given the uncertainty of many influencing factors in urban gas pipeline accident risk assessment, considering the internal urban gas pipeline accident data, the number of urban gas pipeline accidents, 
the causes of accidents, and the types of accidents were investigated. Based on unascertained measurement theory, the risk evaluation model of urban gas pipeline was established. The following conclusions were finally drawn:

(1) Four measure functions based on unascertained measure theory are calculated, a method to determine the risk level according to the recognition criteria of confidence degree is generated, and the risk level of the evaluation pipeline section is determined by this method.

(2) A case study of 10 sections of gas pipeline in a city block is carried out with this theory. The evaluation results of eight sections are consistent under four measure functions. The risk level of the risk evaluation model constructed by the linear distribution measure function is III, and the evaluation result is higher than that of the other three measure functions. The risk level of the risk evaluation model constructed by the exponential distribution measure function is II, and the evaluation result is lower than that constructed by the other three measure functions.

(3) Unascertained measure theory is used to establish the unascertained measure function of each index. Therefore, when using this theory for comprehensive evaluation, considering the evaluation results under different measure functions and focusing on monitoring the objects with different results are necessary.

In this study, four unascertained measure functions: linear, parabolic, exponential and sinusoidal were constructed by the unascertained measure theory, the risk assessment of 10 sections of gas pipe was carried out, and the assessment results were compared. The conclusion provides a new method for identifying key monitoring parts of gas pipeline. However, this study only analyses the differences of four unascertained measure functions on the assessment results of a risk object, and the reasons for the differences between assessment results of different unascertained measurement functions need to be further studied.

\section{Acknowledgements}

This study was supported by the National Key R\&D Program of China (2019YFC0810701).

\section{REFERENCES}

[1] Yu, X. C., Liang, W., Zhang, L. B. et al. (2016). Dual-tree complex wavelet transform and SVD based acoustic noise reduction and its application in leak detection for natural gas pipeline. Mechanical Systems and Signal Processing, 72-73, 266-285. https://doi.org/10.1016/j.ymssp.2015.10.034

[2] Shahriar, A., Sadiq, R., \& Tesfamariam, S. (2012). Risk analysis for oil \& gas pipelines: A sustainability assessment approach using fuzzy based bow-tie analysis. Journal of Loss Prevention in the Process Industries, 25(3), 505-523. https://doi.org/10.1016/j.jp.2011.12.007

[3] Muhič, S., Čikić, A., Pištan, J., Stojkov, M., \& Bošnjaković, M. (2018). Transport emissions and electric mobility in private transport in the Republic of Slovenia. Tehnički Glasnik, 12(2), 98-103. https://doi.org/10.31803/tg-20180508162744

[4] Akhtar, I. \& Kirmani, S. (2020). An application of fuzzy fault tree analysis for reliability evaluation of wind energy system. IETE Journal of Research. https://doi.org/10.1080/03772063.2020.1791741
[5] Akyuz, E., Arslan, O., \& Turan, O. (2020). Application of fuzzy logic to fault tree and event tree analysis of the risk for cargo liquefaction on board ship. Applied Ocean Research, 101, 102238. https://doi.org/10.1016/j.apor.2020.102238

[6] Suh, Y. A. \& Kim, J. (2020). Estimation of the likelihood of severe accident management decision-making using a fuzzy logic model. Annals of Nuclear Energy, 144, 107581. https://doi.org/10.1016/j.anucene.2020.107581

[7] Bakhat, R. \& Rajaa, M. (2020). Risk assessment of a wind turbine using an AHP-MABAC approach with grey system theory: A case study of Morocco. Mathematical Problems in Engineering, 2020, 2496914. https://doi.org/10.1155/2020/2496914

[8] Ganbat, T., Chong, H. Y., Liao, P. C., \& Lee, C. Y. (2019). A cross-systematic review of addressing risks in building information modelling-enabled international construction projects. Archives of Computational Methods in Engineering, 26(4), 899-931. https://doi.org/10.1007/s11831-018-9297-9

[9] Munoz, V. Z., Petz, M., \& Tomas, M. S. A. (2019). Ergonomic risk factors analysis with multi-thodological approach: assessing workers' activities in buildings under construction. Dyna, 94(3), 14. https://doi.org/10.6036/8764

[10] Marhavillas, P. K. \& Vrountas, P. T. (2018). Risk assessment in the constructions sector of EU countries: application of a methodological framework using quantitative techniques and occupational accidents' data throughout the period 19962011. Journal of Engineering Science and Technology Review, 11(1), 66-73. https://doi.org/10.25103/jestr.111.08

[11] Li, X., Ran, Y., Zhang, G. et al. (2019). A failure mode and risk assessment method based on cloud model. Journal of Intelligent Manufacturing, 31(6), 1339-1352. https://doi.org/10.1007/s10845-019-01513-9

[12] Esmaeili, B., Hallowell, M. R., \& Rajagopalan, B. (2015). Attribute-based safety risk assessment. I: Analysis at the fundamental level. Journal of Construction Engineering and Management, 141(8), 04015021. https://doi.org/10.1061/(asce)co.1943-7862.0000980

[13] Esmaeili, B., Hallowell, M. R., \& Rajagopalan, B. (2015). Attribute-based safety risk assessment. II: Predicting safety outcomes using generalized linear models. Journal of Construction Engineering and Management, 141(8), 04015022. https://doi.org/10.1061/(asce)co.1943-7862.0000981

[14] Ning, X., Qi, J., \& Wu, C. (2018). A quantitative safety risk assessment model for construction site layout planning. Safety Science, 104, 246-259. https://doi.org/10.1016/j.ssci.2018.01.016

[15] Huang, G., Sun, S., \& Zhang, D. (2018). Safety evaluation of construction based on the improved AHP-Grey model. Wireless Personal Communications, 103(1), 209-219. https://doi.org/10.1007/s11277-018-5436-8

[16] Gebrehiwet, T. \& Luo, H. (2018). Risk level evaluation on construction project lifecycle using fuzzy comprehensive evaluation and TOPSIS. Symmetry, 11(1), 12. https://doi.org/10.3390/sym11010012

[17] Leśniak, A. \& Janowiec, F. (2019). Risk assessment of additional works in railway construction investments using the Bayes network. Sustainability, 11(19), 5388. https://doi.org/10.3390/su11195388

[18] Dong, G., Wei, W., Xia, X. et al. (2020). Safety risk assessment of a $\mathrm{Pb}-\mathrm{Zn}$ mine based on fuzzy-grey correlation analysis. Electronics, 9(1), 130. https://doi.org/10.3390/electronics9010130

[19] Leu, S. S. \& Chang, C. M. (2013). Bayesian-network-based safety risk assessment for steel construction projects. Accident Analysis \& Prevention, 54, 122-133. https://doi.org/10.1016/j.aap.2013.02.019

[20] Chiroma, H., Khan, A., Abubakar, A. I. et al. (2016). A new approach for forecasting OPEC petroleum consumption based on neural network train by using flower pollination algorithm. Applied Soft Computing, 48, 50-58. 
https://doi.org/10.1016/j.asoc.2016.06.038

[21] Hao, H., Zhang, Q., Wang, Z. et al. (2018). Forecasting the number of end-of-life vehicles using a hybrid model based on grey model and artificial neural network. Journal of Cleaner Production, 202, 684-696. https://doi.org/10.1016/j.jclepro.2018.08.176

[22] Li, W., He, M., Sun, Y. et al. (2019). A novel layered fuzzy Petri nets modelling and reasoning method for process equipment failure risk assessment. Journal of Loss Prevention in the Process Industries, 62. https://doi.org/10.1016/j.jp.2019.103953

[23] Joshi, P., Bikkina, P., \& Wang, Q. (2016). Consequence analysis of accidental release of supercritical carbon dioxide from high pressure pipelines. International Journal of Greenhouse Gas Control, 55, 166-176. https://doi.org/10.1016/j.ijggc.2016.10.010

[24] Wei, Y. R., Li, C. J., \& Wu, X. (2019). Study on calculation method of failure probability for gathering pipeline of shale gas based on Bayesian network. Journal of Safety Science and Technology, 15(1), 121-127.

[25] Wang, G. Y. (1990). Uncertainty information and its mathematical treatment. Journal of Harbin Institute of Architectural Engineering, 23(4), 1-9.

[26] Liu, K. D., Pang, Y. J., Sun, G. Y. et al. (1999). The unascertained measurement evaluation on a city's environmental quality. Systems Engineering-Theory \& Practice, (12), 3-5.

[27] Liu, K. D., Wu, H., \& Wang, N. P. (1997). Uncertainty mathematics. Wuhan: Huazhong University of Science and Technology Press.

[28] Li, S. G., Ma, C., \& Wang, G. Q. (2006). Colliery ventilation safety evaluation on the basis of uncertainty measurement. Journal of University of Science and Technology Beijing, 28(2), 101-103.

[29] Cao, Q. G., Liu, K. Z., \& Zhang, B. W. (2000). Calculation method of objective index weight by entropy. Journal of Hebei Institute of Architectural Science and Technology, 17(3), 40-42.

[30] Li, Y. C., Yang, J., Shi, H. W. et al. (2017). Assessment of sustainable urban transport development based on entropy and unascertained measure. Plos One, 12(10), e0186893. https://doi.org/10.1371/journal.pone.0186893

[31] An, X. W., Li, H. M., Zuo, J., et al. (2018). Identification and prevention of unbalanced bids using the unascertained model. Journal of Construction Engineering and Management, 144(11), 05018013. https://doi.org/10.1061/(asce)co.1943-7862.0001563

[32] Li, H. M., Qin, K. L., \& Li, P. (2015). Selection of project delivery approach with unascertained model. Kybernetes, 44(2), 238-252. https://doi.org/10.1108/k-01-2014-0012

[33] Li, S. C., Wu, J., Xu, Z. H. et al. (2016). Unascertained measure model of water and mud inrush risk evaluation in karst tunnels and its engineering application. KSCE Journal of Civil Engineering, 21(4), 1170-1182. https://doi.org/10.1007/s12205-016-1569-z

[34] Zhou, J. \& Li, X. B. (2012). Integrating unascertained measurement and information entropy theory to assess blastability of rock mass. Journal of Central South University, 19(7), 1953-1960. https://doi.org/10.1007/s11771-012-1231-y

[35] Jia, Q. J., Wu, L., Li, B. et al. (2019). The comprehensive prediction model of rockburst tendency in tunnel based on optimized unascertained measure theory. Geotechnical and Geological Engineering, 37(4), 3399-3411. https://doi.org/10.1007/s10706-019-00854-9

[36] Zhao, K., Wang, Q., Yan, Y. et al. (2019). Geological structural surface evaluation model based on unascertained measure. Geofluids, 2019, 3547384 . https://doi.org/10.1155/2019/3547384

[37] Wu, Q., Zhao, D., Wang, Y. et al. (2017). Method for assessing coal-floor water-inrush risk based on the variableweight model and unascertained measure theory. Hydrogeology Journal, 25(7), 2089-2103. https://doi.org/10.1007/s10040-017-1614-0

[38] Jia, Z. M. (2017). Research on Risk Assessment of Urban Gas Pipeline Based on Unascertained Measurement. Master Thesis, China University of Petroleum-Beijing, Beijing.

[39] Yang, F. \& Wu, C. (2010). Risk assessment on spontaneous combustion of sulfide ore dump in stope based on uncertainty measurement theory. Journal of Central South University (Science and Technology), 41(6), 2373-2380.

[40] Li, W. J. (2014). Study on Essential Safety Evaluation of Life Cycle of Oil-gas Long-distance Pipeline. Master Thesis, Southwest Petroleum University, Chengdu.

\section{Contact information:}

Kai SHENG, PhD

1) Shenzhen Urban Public Safety and Technology Institute,

No. 1, Fuhua 1st Road, Futian District, Shenzhen, Guangzhou, 518000, China

2) College of Safety Science and Engineering, Nanjing Tech University,

Puzhu South Road, Nanjing 211816, Jiangsu, China

E-mail: shengkai0818@163.com

Xiaolin LAl, PhD

Shenzhen Urban Public Safety and Technology Institute,

No.1, Fuhua 1st Road, Futian District, Shenzhen, Guangzhou, 518000, China

E-mail: laix|@szsti.org

\section{Yong CHEN, Master}

Shenzhen Urban Public Safety and Technology Institute,

No.1, Fuhua 1st Road, Futian District, Shenzhen, Guangzhou, 518000, China

E-mail: chenyong@szsti.org

Juncheng, JIANG, PhD, Professor

1) College of Safety Science and Engineering, Nanjing Tech University,

Puzhu South Road, Nanjing 211816, Jiangsu, China

2) School of Environmental and Safety Engineering, Changzhou University,

No.1 Gehu Road, Changzhou, 213164, China

E-mail: jcjiang_njtech@163.com

\section{Lin ZHOU, PhD}

(Corresponding author)

1) College of Safety Science and Engineering, Nanjing Tech University,

Puzhu South Road, Nanjing 211816, Jiangsu, China

2) Shenzhen Urban Public Safety and Technology Institute,

No.1, Fuhua 1st Road, Futian District, Shenzhen, Guangzhou, 518000, China

E-mail: zhoulin8826@126.com 